To appear in

M. Ross and D.T. Miller, eds., The Justice Motive in Everyday Life ( Cambridge U Press, 2001)

\title{
Retributive Justice: Its Social Context
}

\author{
Neil Vidmar
}

As for the social character of [penal] reaction, it comes from the social nature of the offended sentiments. Because they are found in all consciences, the infraction committed arouses in those who have evidence of it or who learn of its existence the same indignation. Everybody is attacked; consequently, everybody opposes the attack. Not only is the reaction general, but it is collective, which is not the same thing. It is not produced isolatedly in each one, but with a totality and a unity, nevertheless variable, according to the case.

(Emile Durkheim 1893/1964:102)

Emile Durkheim, George Herbert Mead (1918), Thomas and Znaniecki (1945 ) and, in more recent times, Harold Garfinkel (1956) and Kai Erikson (1966), commented extensively on the fact that deviant acts evoke group responses. In Erikson's summary phrasing:

The deviant act, then, creates a sense of mutuality among the people of a community by supplying a focus for group feeling. Like a war, a flood,

or some other emergency, deviance makes people more alert to the interests they share in common and draws attention to those values which constitute the "collective conscience" of the community. (1966:4)

Until relatively recently, social psychologists have given less attention to retributive justice than to other forms of justice, such as distributive and procedural justice ( see Vidmar, 2001). Although interest in retributive justice is increasing, the fact remains that social psychological research on retribution has tended 
to ignore, or at least downplay, the insights of sociologists in deference to an approach that examines how individuals respond to deviant acts. Without rejecting psychological analyses, this chapter draws attention to the social context and social consequences of retributive justice. Group dynamics are at play in a wide array of settings in which people respond to rule or norm violations, but in this essay I will draw primarily upon more than a quarter century of research, much of it previously unpublished, that examines community reactions to criminal events. However, at the end of the essay I argue that the issues raised by the research can and should be tested in more mundane settings in which rule violations occur.

The theme of this chapter is quite consistent with Mel Lerner's more general theorizing about the social psychology of justice ( Lerner, 1981). Lerner argued that justice is a universal motive and humans care deeply about justice. Justice judgments invoke evaluative and emotional assessments. Lerner (1987) persuasively argued that much research on justice has been carried out in experimental settings that minimize affectivemotivational processes, and that there is an important need to test theoretical notions of justice in more complex settings that give sway to these inherent human factors. Lerner's research has also focused on the sequaele of justice judgments as well as on their antecedents. To wit, justice judgments have behavioral consequences (e.g. Lerner, 1977). Finally, Lerner argued that identity relationships are very important, that is, persons perceived to be members of in-groups are treated differently from members of out-groups.

\section{A Social Psychological Perspective}

I have no quarrel with the view that retributive justice reactions are represented in the minds of individual persons and involve attributional responses, but there is much more to the phenomenon. In a recent writing (Vidmar, 2001) I proposed a six-stage model of the social psychological dynamics of retribution: (1) there is a perceived rule or norm violation;(2) the rule violator's intention is perceived as blameworthy; (3) the combination of (1) and (2) threatens or actually harms values related to the perceiver's personal self, status, or internalized group values; (4) the emotion of anger is aroused; (5) the cognitions and emotions foster reactions against the violator; (6) during or following punishment the anger dissipates, cognitions return 
toward homeostasis, and the rule or norm is perceived to be vindicated.

The model posits emotion as a core component of retributive justice reactions. It allows for the fact that some of the stages may occur out of sequence. It also takes cognizance of Heider's (1958) observation that justice reactions are often in an amorphous, inchoate form in the minds of responders, and articulation of them typically takes the form of "oughtness" words and phrases such as "deserves," "do justice," or "right a wrong."

The model also contains the codicil that, in some circumstances, punishment of the offender may actually increase psychological and social tension because the act of punishment of the offender serves to validate the perception of harm to the values which the rule incorporates. Although I know of no research that has directly tested this hypothesis, it is often argued indirectly in criticisms of the effect of capital punishment. The writings of Rene Girard $(1986 ; 1987)$ analyzing scapegoating from the Twelfth century to the present suggest that threats to social organization and norms evoke punitive responses that are transformed into beliefs and rituals that see the community as victims and reinforce that sense of victimhood.

Now, while the model clearly recognizes that retributive impulses arise in individual psyches and are represented and expressed in behaviors of individuals, there is also a social context. More than two decades ago Dale Miller and I (Vidmar and Miller, 1979; see also Vidmar, 2001) drew upon the writings by the sociologists cited above as well as by Fritz Heider (1958) to insist upon the importance of norms in understanding retributive impulses. We argued that studies of retributive justice must consider motives involving group membership functions as well as punishment targeted on the offender. While rule offenders are punished in order to change the rule offender's belief system vis as vis the victim or societal rule, to reaffirm the self image of the victim, to assert power over the offender and to differentiate the offender from other members of the group, punishment also serves important functions bearing on group cohesion, particularly in solidifying support about the legitimacy of group norms among the non-offending members of the group. Punishment vindicates societal rules, it helps to establish social consensus about the validity and legitimacy of the rules, it releases social tension about the rule violation through social comparison processes, and it serves to restore group cohesion. A second quotation from Durkheim (1893/1964:102) is useful at this point because it helps to set the stage for the discussion that follows:

Crime brings together upright consciences and 
concentrates them. We have only to notice what happens, particularly in a small town, when some moral scandal has just been committed. They stop each other on the street, they visit each other, they seem to come together to talk of the event and to wax indignant in common. From all the similar impressions that are exchanged, for all the temper that gets expressed, there emerges a unique [public] temper.

Durkheim's observation has been endorsed by other sociologists. Thomas and Znaniecki (1945) concluded that in Polish peasant communities, punishment served the important purpose of obtaining consensus about the rules that were violated. Kai Erikson's (1960) study of the Salem witch trials explored the social context in which Puritan society was embedded. He concluded that a central dynamic of the phenomena that led to the trials was social change that threatened the normative values and beliefs of Puritan society. Punishment of alleged witches served to affirm the correctness of Puritan beliefs. Similar dynamics are evident in modern societies and affect retributive justice reactions. Consider the case studies described in Section II.

\section{Retributive Impulses and Infamous Crimes}

R. v Iutzi: In 1978 a two-year-old child was found dead in a rural county in Ontario (see Vidmar and Melnitzer, 1984). He had died of head injuries. The child's mother and father were both charged with second degree murder, with each denying responsibility for the death and each accusing the other. Both parents had worked at a variety of menial jobs around the county, were frequent hitchhikers on rural roads, and were notorious for searching through trash heaps. A court order proscribed publication of any court proceedings, thereby resulting in almost no mass media coverage of the event. Nevertheless, a survey of the county conducted on behalf of the defendants indicated that community gossip about the event was extensive and highly prejudicial to the accused. Community members discussed the case at home, with friends and at work. The survey revealed that there was a clear sense of community shame and consternation that such a 
thing could happen in their community. Its questions elicited comments like the following: "That happens in big cities [like Toronto or Detroit], not nice places like here;" and "it's a terrible shame on all of us." The survey also revealed strong beliefs that even if the mother had not killed the child herself, she should be held responsible and punished because "a mother is responsible for her child." Subsequently, some prospective jurors questioned in court revealed strong beliefs not only that one or both defendants were guilty, but reinforced the survey findings that most members of the community believed that the killing had brought shame to the community.

The Mount Cashel Cases: In 1989 a number of members and former members of the Congregation of Christian Brothers of Ireland, a Catholic religious order, were charged with sexually and physically abusing young boys who were under their care in the Mt. Cashel Orphanage in St. John's, Newfoundland, Canada during the 1970s (see Ogloff and Vidmar, 1994). The allegations did not come to light until after some of the victims were in their twenties. The government of Newfoundland set up a Royal Commission of Inquiry to ascertain if earlier reports of the abuse had been covered up by church authorities and government officials. The hearings were televised across Canada and shocked the nation when victims testified about the sexual abuse that took place in the orphanage. The former inhabitants of the orphanage described in graphic detail sexual acts perpetrated on them by various Christian Brothers ( see Ogloff and Vidmar, 1994 for examples). The effects were most profound in St. John's itself, a community of approximately 160,000 persons, that is steeped in fishing and seafaring tradition and often described as a small town wedded to continuity rather than change. It is important for present purposes to indicate that the sense of historical continuity also involves uneasy currents of differences between Catholics and Protestants over religion and political and social influence. These divisions go back generations and remain deep, even in contemporary Newfoundland society. $^{1}$

Not surprisingly, the uncovering of the Mt. Cashel events had profound effects on the St. John's community, causing extensive community discussion and numerous articles and letters to the editor in local papers (Vidmar, 1991). For instance, one newspaper article referred to "this blight on the social consciousness of Newfoundlanders." Another compared the Mt. Cashel events to Buchenwald and went on to state: “...the vast majority of us rejoice that justice has been done, and we thirst for justice for those victims of the sadists

\footnotetext{
${ }^{1}$ Although a novel, Wayne Johnston's engrossing book, The Divine Ryans (1990/1999) and the movie of the same title provides context for these sentiments and divisions in Newfoundland. In several interviews that I conducted in St. John's during August, 2000 I learned that the repercussions from the Mt. Cashel cases continue to affect the community. The religious divisions remain, with Catholics still on the defensive. Although perpetrators were sentenced to prison, further criminal proceedings have continued sporadically. Most of the victims have not received promised financial compensation and retributive feelings in the community remain high.
} 
and perverts who have allegedly desecrated the halls of Mt. Cashel with unspeakable acts of cruelty and licentiousness." Another described the need to purge and cleanse the community, another asserted a "moral chanchre eating away at the fabric of Newfoundland society" and another referred to "a collective moral collapse, a corruption of community." A survey of the community and interviews with St. Johns inhabitants in June 1991 uncovered high degrees of community discussion and gossip about the events and a desire to have the accused severely punished (Vidmar, 1991). However, the very strongest reactions came from Catholics rather than Protestants. The perceived betrayal by their priests and the Christian Brothers ate at the very core of their faith and destroyed their private and public sense of religious and moral superiority over the Protestants.

Kidnaping and Death on the Shores of Lake Huron: In January 1988 Julie Bowers, a resident of Kincardine, Ontario, parked her car in front of a downtown donut shop and left her sleeping eleven-month-old boy in her unlocked car. When she came out a short time later, the child was missing. Frantic, she called the police and stated that her son had been kidnaped. ${ }^{2}$ Local police in the town of 6000 persons on the shores of Lake Huron contacted provincial police and a province-wide search for the kidnapper was undertaken. A day later the child was found in a snow covered field outside of Kincardine, dead of hypothermia. After further police investigation Bowers was charged with murder. Much was written about the case in the local and national papers and much gossip occurred within Kincardine and surrounding communities. Much of it concerned the reputation of small-town Kincardine in the eyes of the world. Some examples are as follows: "This is perfect fodder for the rumor mill...and there are ugly rumors;" "almost everybody has prejudged the case;" "We're being belted left, right and center [by the media attention] -you'd think we were a big city or something." Strikingly, both the rumor mill and the local newspaper accounts continuously emphasized that while Julie Bowers' husband and family were lifelong residents of Kincardine, Julie was an outsider to the community: e.g. "Mr. Bowers is a lifelong resident of Kincardine... while Julie emigrated from England ten years ago."

\section{The violation of community values}

In the three Canadian cases described above, it is important to observe that they all involved homogeneous and relatively crime-free communities that were shocked by crimes that threatened perceived unique values of those communities. While Canadians outside those jurisdictions also exhibited punitive attitudes toward the alleged perpetrators, the responses in the local communities were exacerbated by the challenge to community values. Like the French towns observed by Durkheim, the Polish peasant societies described by Thomas and

\footnotetext{
${ }^{2}$ This summary is based upon unpublished data that was tendered in testimony in the Supreme Court of Ontario ( Trial Division) in January, 1989on behalf of a defense motion to have the Bowers trial moved from Kincardine to Toronto and on an unpublished student paper written by Liane Taylor in April 1990.
} 
Znanecki (1902) and Erikson's Puritan communities the reactions involved gossip and rumor that included attempts to achieve consensus about local values and to assert their legitimacy.

Although there is not space in this chapter to provide details, it is important to note that although the primary data in these cases were derived from randomly selected individuals responding to surveys, the questions assessed, with both closed- and open-ended items, the degree to which the respondents had discussed the case with others. Respondents' verbatim comments produced additional evidence and in some cases the survey data were supplemented by in-depth interviews with members of the community and newspaper accounts. The data strongly indicated that the attitudes were not developed in isolation, but rather through a process of social interaction.

These are not unique cases. Edward Bronson (1989) documented the effects of rumor and gossip involved with a brutal inter-racial killing in a small Florida town. As one prospective juror in that community testified, "It was impossible to stop and have coffee in this county for three or four weeks without hearing about [the case]."

Similar reactions occur in more urbanized settings. The bombing of the Murrah Federal Building in Oklahoma in April 1995 with the loss of so many lives also caused discussion, rumor and gossip throughout the United States (see Studebaker et al., 2000). It, too, threatened values and evoked calls for the death penalty as punishment. Importantly, citizens of Oklahoma City, where the bombing occurred, were stronger in their reactions and calls for justice than other Oklahoma communities. Indeed, after reviewing testimony and survey data Judge Maitch of the U.S. District Court concluded that "the entire state had become a unified community, sharing the emotional trauma of those who had become directly victimized" (U.S. v. Mc Veigh,1997). ${ }^{3}$ Denver, Colorado, further removed from the death, destruction, and personal knowledge of victims, had the lowest reactions of the cities studied. These case studies strongly suggest that the more criminal events threaten group or community values, the stronger will be the punitive reactions and attempts to achieve consensus to reaffirm those values. The dynamics of this process are consistent with those analyzed in Allport and Postman's (1947) classic text, The Psychology of Rumor, and Smelser's (1963) classic text, Theory of Collective Behavior.

Tyler and Boeckman (1997) explored the issue of moral factors in a different way in their examination of public support for California's "Three Strikes Law." In 1994 California voters passed a ballot initiative that

\footnotetext{
${ }^{3}$ In the decision to move the trial from Oklahoma (U.S. v. McVeigh, 1996) the court reviewed many sources of evidence and concluded that Oklahomans were "united as a family," that there was "extraordinary provocation of their emotions of anger and vengeance," that there was "a prevailing belief that some action must be taken to make things right again," and that the common reference in articulating these feelings was "seeing that justice is done."
} 
mandated a life sentence for any person convicted of three felonies. The law, which is highly punitive in its intent and effect is consistent with other punitive trends in American society (see, e.g. Ellsworth and Gross). Tyler and Boeckman conducted a survey involving a random sample of adults in Northern California to test three hypotheses about bases of support for the three strikes law. The survey assessed crime related concerns, concerns about social conditions and social values. From these data two main concepts were compared: an instrumental judgment that the world is dangerous and non-instrumental judgments. ${ }^{4}$ These latter judgments involve beliefs that rule breaking is an affront to social and moral values and norms. Although the instrumental and symbolic expressions of attitudes were positively correlated, support for the three strikes initiative and expressions of general punitiveness were best predicted by concerns that the contemporary world lacks moral cohesion. Indeed, persons holding strong concerns about moral cohesion were willing to abandon procedural protections for persons charged with criminal offenses.

\section{Outsiders as Explanations of Deviance}

An interesting facet of the Bowers "kidnaping" case involved many comments that Julie Bowers was not part of the community, that she was an outsider. The newspaper accounts and informal gossip continually stressed her English background, implicitly suggesting that a community insider would not have been capable of an act of leaving one's child to die in the woods. These expressions can be interpreted as attempts to explain why community norms were valid, that only an outsider would be likely to violate them. In the Iutzi case the parents were notorious outsiders, social outcasts, long before their child was found dead. The mother was widely known for having mental problems and the father for excessive drinking and engaging in altercations. Thus, even though they were members of the community in one sense they were clearly viewed as deviants. Rene Girard's (1986;12-14) literary analyses of the scapegoating of individuals or ethnic, religious or racial groups from the time of the Black Death in the fourteenth century to the present day led him to conclude that persecutions by mobs generally occur in times of crisis, with an extreme loss of social order. There is an increased reciprocity of negative exchanges, a common reaction of ignoring any internal divisions in the community, and an assumption that there is a unitary view about internal normative states as contrasted with the outsiders who are blamed for the conditions affecting the community.

\section{Apostates and Retributive Justice}

The deviant acts of the Christian Brothers posed a different problem than in the Bowers and Iutzi cases. The Brothers had been viewed as leading members of the Newfoundland community, particularly among

\footnotetext{
${ }^{4}$ Tyler and Boeckman use the term "relational" for these non-instrumental concerns.
} 
Catholics. Thus, for Catholics the crimes were a form of apostasy that threatened cherished beliefs about the Catholic sub-community and increased judgments of their heinousness. Their reactions, relative to reactions of Protestants, were much more strident. Indeed, all of the quotations reported in my summary of the Mt. Cashel cases - the need to "cleanse the community," the "moral chanchre," the "collective moral collapse," and the "corruption of community" -are quotations from Catholic writers.

Lessons can also be learned from the death sentence imposed on author Salman Rushdie for publication of his novel, The Satanic Verses. ( Pipes, 1990; 1998). Although there are complicated political issues entwined in the Rushdie matter, a basic element is the fact that fundamentalist Muslims are very sensitive about disparagement of their religion in Western media and tend to view fictional works in a singularly literal way. They view the power, wealth and secularism of the West as antithetical and threatening to their religious beliefs. The particular hatred toward Rushdie among fundamentalists can be ascribed to the fact that Rushdie "is, or was born, a Muslim; by rights he should protect the reputation of the Prophet Muhammad, not mock it"( Pipes, 1990:14). Moreover, the fact that Rushdie lives in England and writes in the West "suggests that Rushdie has in some way joined the Christian world, that his allegiances have changed"(Pipes,1990:14). Rushdie may have further exacerbated hatred toward him by a statement in 1990 affirming his own Islamic faith but subsequently retracting the statement and referring to his enemies as "dinosaurs [who] represent absolutely nothing"(Pipes,1998).

In short, social harm to the community is far worse when the deviant acts are committed by those who are ingroup members than when they are committed by outsiders. The acts are not only viewed as a violation of rules, but an explicit rejection of the norms and values by one who is required by group membership to adhere to them. Thus, the acts are far more threatening to the members of the community who subscribe to the values. The reaction is further exacerbated when the acts come to the attention of outsider groups that are viewed as competing with the ingroup, because the deviance lowers the ingroup values relative to those of the out-group. Pipes (1990) suggested that if Rushdie had written his work from within the heartland of Islam and exclusively for a Muslim audience the reaction against him might have been less extreme.

\section{Excuses and Other Mitigating Conditions}

Research into the social psychology of justice has centered on the effects of excuses and justifications, simultaneously drawing parallels with legal excuses and other mitigating factors in criminal responsibility( see,

e.g. Darley and Zana, 1982; Heider, 1956; Schultz and Darley, 1991). The studies of individual reactions to hypothetical vignettes, most often involving college students as subjects, generally show that excuses and 
justifications mitigate retributive punitive reactions ( see Vidmar, 2000a for a partial review). In field studies these findings are not always supported.

In R. v. Theberge (1994) a 37-year-old male stalked, stabbed and killed the teenage daughter of a local doctor in a northern Ontario community. ${ }^{5}$ Not withstanding the facts that until shortly before the crime the accused had been a responsible worker and family man with no prior criminal record, that he immediately ran to the police station to euphorically confess his crime and that later evidence indicated that he suffered from a large brain tumor, many members of the community refused to consider any exculpatory evidence and insisted on severe punishment. Indeed, a survey of the community taken approximately four years after the killing found that $52 \%$ of the respondents would consider a trial verdict by judge and jury of not guilty by reason of insanity to be either unacceptable of very unacceptable. To be sure, some of those respondents were concerned about having the accused back in the community, but many expressed the reasoning that Theberge had to be held responsible and punished.

In R.v. McGregor (1991) the estranged husband of a Canadian government lawyer killed his wife in downtown Ottawa using a cross-bow. ${ }^{6}$ The killing occurred on the anniversary of the 1989 Montreal massacre in which 14 female engineering students were killed by a lone gunman. Survey research in the Ottawa community a year later found that most respondents reported that they had discussed the case with family members, neighbors or co-workers. Similar to the Theberge case, 59 percent of respondents reported that they would consider a trial verdict of not guilty by reason of insanity by a judge and jury as unacceptable or very unacceptable.

The insanity defense is a special case, ${ }^{7}$ but the findings from these studies also raise important questions about the robustness of effects of other justifications and excuses when they are interpreted in the context of community sentiments about infamous acts. McGraw (1991) has provided a useful classification of excuses and justifications. Excuses entail offering reasons involving past or present mitigating circumstances, horizontal or vertical diffusion of responsibility and pleas of ignorance. Justifications involve explanations that the acts need to be seen in the context of past or present benefits that accrue from their results, comparisons to past acts or acts of others, comparisons to hypothetical situations, rules of fairness, and acts of conscience.

\footnotetext{
${ }^{5}$ This summary of the Theberge case is based on an unpublished affidavit dated May 20, 1994 that was tendered in a change of venue hearing in The Ontario Court of Justice (General Division) (North East Region).

${ }^{6}$ This summary is based on an affidavit submitted to the Ontario Court of Justice ( Ottawa Region) in December, 1992 with respect to a defense motion to have the accused tried by judge alone, rather than by judge and jury.

${ }^{7}$ In considering the implications of the findings of these two studies, it must be noted that 17 percent of respondents in the McGregor case and 13 percent of respondents in the Theberge case stated that they would never accept an insanity defense in any case. Some of the reasons given involved utilitarian concerns that the defendant would be released and could kill again, but the predominant reason involved explanations that mental illness was no excuse to escape retributive punishment.
} 
Research by Hamilton and Sanders (1992) explored some of these factors in their study of role responsibility in samples of Japanese and American respondents. They found that blame attribution is contingent on at least two factors, namely what the person did and what the person was obliged to do.

Gibson and Gouws (1999) utilized these insights in a study of reactions to the South Africa's Truth and Reconciliation Commission. During the years of apartheid, members of the government security forces and members of the forces struggling against apartheid committed many atrocities against the other side or against innocent civilians, sometimes on the barest of suspicions. In 1998 the "Promotion of National Unity and Reconciliation Act," intended to heal the wounds of that era, provided for amnesty of persons of either side who confessed their deeds. In anticipation of the adoption of that Act, Gibson and Gouws conducted a panel survey involving South Africans of all races in 1996 and 1997. They presented respondents with vignettes of a person who confessed to nefarious acts. Half of the respondents were told that the person was an agent of the South African Security Forces and half were told he was a member of the military wing of the African National Congress. Other factors were manipulated within each of these conditions: whether the person was a leader or a follower; whether the deaths caused by the person were combatants or persons not involved in the struggle; and whether the perpetrator acted out of hatred toward the racial group or out of ideological motives. Respondents in the survey were asked to make judgments about blameworthiness of the perpetrator and whether he should be forgiven or punished. Racial differences among respondents were complex, but Gibson and Gouws concluded that race affected the perceptions of the blameworthiness, with whites more forgiving of a government perpetrator and blacks more forgiving of an ANC perpetrator, albeit the processes through which the two groups ascribed blame did not substantially differ. Respondents who ascribed greater blame to the perpetrator were more likely to state that he should be punished rather than forgiven. Leaders were judged more responsible for their deeds than followers. However, one of the most interesting findings was that an excuse of noble motives (acting out of ideology rather than racial hatred) did little to exonerate the violent acts. Finally, whether the victims of the acts were innocent civilians or combatants made little difference in judgments of blame or desire to punish. For our present purposes the most important finding involves the racial differences between respondents because they demonstrate that group membership mediates retributive responses

The racial effects in the Gibson and Gouws study has a rough parallel to differences between African Americans and whites in reaction to the O.J. Simpson case, involving the brutal slaying of his wife and her friend, Ron Goldman. In this instance, however, the pattern between whites and blacks was reversed. A survey by Graham, Weiner and Zucker (1997) during the week following Simpson's arrest found that whites were more 
likely than African Americans to infer Simpson was responsible for the crime, to feel more anger, and to believe that he should be punished to extract retribution, as well as to deter others. These racial differences in perceptions of the Simpson case were enhanced after Simpson's acquittal, indeed causing more than one commentator to conclude that "the trial clearly demonstrated how ethnicity trumps both gender and class in terms of group solidarity (Cerroni-Long,1996; and, generally, Barak, 1996; Linedecker,1995).

Effects of Apologies and Remorse on Retributive Sentiments

Similar to excuses and justifications, there is a body of social psychological literature that has examined the effects of apologies and expressions of remorse by rule violators on punitive attitudes ( see Vidmar, 2001, for a review). For instance, Robinson and Darley (1995) presented respondents with a set of scenarios involving a locksmith who considered stealing or actually completed the theft. In some conditions the locksmith was remorseful or attempted to return the coins. In these remorse conditions respondents tended to report that he should not be held liable, or if liable, should not be punished. Kleinke, Wallis and Stalder (1992) conducted an experiment that found that a rapist's expression of remorse lessened recommended prison sentences. However, a study by Taylor and Kleinke (1992)found that while expressions of remorse affected judgments about a drunk driver who caused a death, remorse had no effect on recommended sanctions. In an experiment involving a drunk driving death Robinson, Smith-Lovin and Tsoudis (1994), however, found that expressions of remorse, as reflected in the culprit's non-verbal behavior during a confession, resulted in lesser sentences. The remorse affected respondent's perceptions of the offender's social identity.

Because of other factors including the extreme emotions aroused in the Rushdie controversy, it is questionable whether Salman Rushdie would have placated his fundamentalist critics if he had offered a sincere and complete apology (see Pipes, 1990; 1998) but the fact that it was considered suggests the importance of apologies for the community that is offended by the rule violation. Apologies serve the dual purpose of helping to integrate the offender back into the group and to reaffirm the moral basis of the rule that was violated. Kai Erikson's(1966) research on Puritan society with regard to the witchcraft trials, ${ }^{8}$ is strongly supportive of Durkheim's thesis that deviance helps to define the boundaries of society and supplies a focus for group feeling. Throughout a period of social upheaval in which these events occurred, the trials of heretics and witches continually focused on confessions. Erikson observed that, strikingly,

\footnotetext{
${ }^{8}$ Erikson also explored an arcane doctrinal controversy between factions of the Puritans and an invasion of Quakers into their communities that preceded the witchcraft trials and probably contributed to the social uncertainty.
} 
...none of the executed witches had confessed and none of the many confessors had been executed. Far from establishing guilt, a well-phrased and tearfully delivered confession was clearly the best guarantee against hanging. (1966:152)

Although there were other forces in play, it is apparent that confessions supported the validity of the Puritan's religious and other world views and thus reduced the tendency to levy the most harsh punishment. In this context the effects of confessions and remorse can be examined in a modern context with respect to jury verdicts for life imprisonment rather than capital punishment. Sundby ( 1998)studied thirty-seven sentencing hearings and conducted interviews with jurors who had participated in them. In 19 cases the defendant received a death sentence, in 17 the defendant received a life sentence without parole, and one case involved a jury that was split on the appropriate penalty. The main purpose of the research was to examine the effects of juror perceptions of remorse in sentencing decisions. While remorse can affect utilitarian considerations about potential dangerousness, the interviews reflect a sense of anger about lack of remorse that strongly suggests retributive purposes of punishment. The interviews were with individual jurors, but unlike many studies of punishment attitudes the jurors had deliberated as a group and although they were charged with working within legal guidelines their discussions reflected and considered community values. Sundby's research uncovered the fact that jurors closely scrutinize defendants' demeanor and behavior throughout the trial, and that these impressions play a significant part in their verdict on life or death. Strikingly, jurors reported that in almost all of the cases, both those resulting in a death verdict and those resulting in a life sentence verdict, defendants in these murder cases exhibited a lack of emotion during the trial. These included even the times when the prosecutor introduced horrific evidence depicting the crimes. The perceived attitudes of nonchalance, or even boredom, provoked astonishment and anger in the jurors. However, a distinguishing characteristic between death versus life verdicts was arrogance and attitudes of defiance in the death sentence defendants: e.g. "We saw no remorse - almost a cocky attitude;" "The defendant acted as though the entire trial was a farce. It seemed as if he resented the fact that he had to be put through the process, as if we were inconveniencing him," (Sundby :1564- 65). As one juror stated, the jury did not expect the defendant to beg for his life, but if he had indicated sorrow for what he did the decision might have been for life. Another factor was when the defense was a denial of responsibility for the killing. Verdicts for life sentences occurred in two cases when the defendant admitted the killing and expressed regret in both substance and manner. In most of the remaining life cases the jurors could not reach a consensus on the issue of remorse. 
Remorse, whether in Puritan Salem or in modern day murder trials, appears to serve the function of reaffirming moral values held by members of the community.

\section{Failures to Punish}

There is another issue about the social functions of retribution raised by the Julie Bowers case. What if the punishment is viewed as insufficient for the crime or there is no punishment at all? Bowers' trial was moved from Kincardine to Toronto and she was found not guilty. ${ }^{9}$ The trial produced evidence that was exculpatory of her. (There were indications that a relative may have taken the baby to teach Bowers a lesson about leaving children in cars and who panicked and and left it in the woods when the police were called.) Nevertheless, many members of the Kincardine community remained convinced of her guilt and felt that a great injustice had occurred. There was even concern for her safety when she eventually returned to the community and to her husband.

In another case, R. v. Reynolds (see Vidmar, 2000), a young woman was charged with stabbing her sevenyear-old daughter 84 times in September 1997. She denied the killing and there is alternative opposing evidence that the daughter may have instead been killed by a pit bull. ${ }^{10}$ Although community gossip was high at the time that the mother was charged, on the one- year anniversary of the child's death the local newspaper printed a memorial poem written by the mother that aroused such intense anger in some segments of the local community that a confidential memorandum by the police expressed concerns for Reynold's physical safety. A survey of the community almost three years after the child's death ( in June 2000) found many respondents remained frustrated and hostile because Reynolds still had not been punished for her alleged guilt.

In the Oklahoma bombing case the retributive feelings among families of victims and persons with no familial connections to the victims are so great that even though co-conspirator Terry Nichols was sentenced to life imprisonment, responding to community pressure, prosecutors in the State of Oklahoma moved for a separate trial that could result in a death penalty for Nichols ( Rovella, 1998; 1999; 2000).

Similar social psychological dynamics appear behind the victims rights movement in the United States and in other Western democracies(Fletcher, 1995; Mosteller, 1997; Sarat,1997). The formal legal process in most countries has long preempted victims from participating in the prosecution of criminals. The process of punishment is seen as the duty of the state. However, the victim's rights movement is an attempt to move

\footnotetext{
${ }^{9}$ See footnote 1 for the source of this discussion.

10 The trial was delayed for a number of legal reasons and has not gone to trial at the time of this writing.
} 
victims of crime back into an active role in the criminal trial by allowing victim impact statements during the trial. Much of the rhetoric in favor of the movement involves strong themes of retribution ( see especially, Sarat, 1997). The movement has some broad social and political support and has gained a foothold in case law that allows victim impact statements in the trial process. While reliable empirical research on the bases of community support for the movement is lacking, it is likely that the explanations for it reside in attitudes similar to those explored by Tyler and Boeckman (1997) regarding California's "Three Strikes Law,"namely affronts to moral values.

It is worth noting that Spanish law allows victims of crimes or their survivors to hire lawyers and prosecute cases as third parties in criminal trial proceedings and a rough similarity is also built into new Russian laws ( Thaman, 2000). An interesting question is whether these procedures ameliorate victims' feelings that retributive justice is unrequited in the legal process. ${ }^{11} \mathrm{~A}$ related question is whether victim impact statements are a form of giving voice to retributive sentiments that reduce aggression and feelings of delegitimation of the legal process, or as suggested by Sarat (1997), that they have the potential to further inflame and create retributive behaviors by personalizing the legal process.

Similar issues arise in respect to proposals for "shaming penalties" as an alternative punishment for certain crimes (Brathwaite, 1989; see also Rosen,1993; Will, 1996). Shaming penalties were common in Colonial times (Rosen,1993). The basic theory behind these contemporary proposals is to focus on developing the morality of the offender, eliminating the dysfunctional consequences of incarcerating legal rule offenders, and allowing them to be integrated back into the community. Some judges have tried this form of punishment. In North Carolina a judge sentenced a 27- year-old woman whose drunk driving accident resulted in a death to three years probation (Rochman, 1999). As part of the sentence the driver was required for the first year to carry a sign stating "I am a convicted drunk driver and as a result I took a life" in front of the court house one day each month for the first year. In the North Carolina case a newspaper photograph shows members of the victim's family watching the offender as she carried the sign. The family members expressed satisfaction with the penalty, stating that probation was insufficient. Shaming penalties have also been utilized in aboriginal communities with some claimed success in re-integration of the offender and placation of victims. (Griffiths and Hamilton, 1996; Stuart 1996). Shaming was part of traditional aboriginal culture, but there is evidence indicating that even in these societies shaming may be deemed insufficient for certain crimes and certain offenders because of the community's need for greater retribution. Thus, questions arise

\footnotetext{
11 I am not unmindful that this question is relevant to the extensive literature on psychological catharsis ( Feshback, 1984; Scheff and Bushell,1984), but do not have space to explore it in this chapter.
} 
about the effectiveness of shaming as a substitute for other punishments in order to satisfy retributive needs, particularly when there are few cultural supports for it ( Rosen, 1993).

\section{Concluding Comments}

Field studies of criminal cases provide evidence that retributive responses to criminal events are socially derived, or at least are mediated by social interaction. They also provide evidence that crimes have group as well as individual consequences, consistent with the theorizing of sociologists.

The experimental and field research of Nisbett and Cohn (1996) on the culture of honor is, I believe, directly relevant to the phenomenon of retributive justice (Vidmar, 2000a) because studies in that program of research directly examine cultural differences in behavioral reactions to violations of social norms. The research of Felson (1978; Felson and Tedeschi, 1995) and others (e.g. Bond and Harris, 1991) examining reactions to insults involving group membership and group cohesion variables and the effects of cultural differences also provides insights about retributive responses. Research on group identity theory (e.g. Abrams and Hogg, 1990; Tajfel, 1978; Marques, 1990) may also provide insights into retributive justice. However, even in this research the emphasis has been on individual cognitive responses. Not only has the role of emotions been largely ignored, almost no research on retribution has focused on groups as a dependent variable. During the middle of the twentieth century Kurt Lewin, Leon Festinger, Stanley Schachter and many others had a genuine interest in group phenomena ( see Cartwright and Zander, 1960). It seems clear that concepts like group cohesion and social comparison processes are very important in understanding how people respond to real world violations of norms and values. Studies of retributive justice need to focus on these phenomena. In my chapter reviewing the dynamics of retributive justice ( Vidmar, 2000a) I argued that much more research needs to be addressed to retributive responses in non-criminal settings. In this call I have only echoed insights from Hans Kelsen (1943) Fritz Heider (1958)and Hogan and Emler (1981). Retributive justice reactions occur in formal and informal settings as diverse as the nuclear family and large corporate organizations. In short retributive justice is relevant to all aspects of human life. And the basic dynamics of retributive responses appear generally similar across all domains. 
There are some methodological advantages to studying retribution in non-criminal settings. It is much easier to devise experiments to test the relationship between variables. As an example it is most appropriate to conclude a chapter in a book honoring Mel Lerner by using one of his studies as an example.

Meindl and Lerner (1983) conducted an experiment in which a confederate engaged in an unprovoked verbal assault denigrating the intelligence and personal integrity of a student subject, the subject's assigned partner (whom the subject had not met and would not physically meet) or a third party. Subsequently, the subjects were provided the opportunity to punish the social norm violator, although at a cost of lost earnings to themselves. In the condition involving attacks against a third party, subjects avoided contact with the verbal abuser. If they personally were the target of the assault subjects were more likely to punish the offender, but the strongest punishment responses occurred when their partner had been the target of the attack. Meindl and Lerner explained these data by reference to the fact that the experiment made salient group norms requiring people to protect other group members. Meindl and Lerner's experiment can clearly be interpreted as a study of retributive justice and, indeed, Lerner (1987) subsequently has done so.

I am tempted to devise here and now a thought experiment on how the Meindel and Lerner methodology could be adapted to look at group variables in order to follow my own advice about thinking about group variables more broadly conceived. But that is for another day.

The main goal of this chapter( see also Vidmar, 2000a) has been to provoke thought about the narrowness of focus that characterizes much of the experimental research on retribution. That narrowness includes a focus on individuals without considering group dynamics. The narrowness includes a focus on cognitive elements to the exclusion of affective elements in retributive dynamics, particularly those aroused and reinforced through social interaction. And the narrowness includes a focus on the antecedents of retributive impulses without consideration of the consequences after those impulses are aroused. Finally, most of the material reviewed in this chapter involves field studies and correlational research. The materials are a rich source of hypotheses, but lack the ability to rule out alternative explanations for observed phenomena. There is a great need for controlled experiments that can clarify cause and effect relationships in the dynamics of retributive justice.

\section{References}


Abrams, Dominic and Hogg, Michael, eds, (1990). Social Identity Theory : Constructive and Critical Advances. New York Springer-Verlag.

Allport, Gordon and Postman, Leo (1947). The Psychology of Rumor. New York: H. Holt and Co.

Greg, ed, (1996) Representing O.J. :Murder ,Criminal Justice and Mass Culture. Guilderland, NY: Harrow and Heston. 
Michael

and

Venus,

Chung

Kwok

(1991).

Resis-

tance to

Group

or Per-

sonal

Insults

in an

Ingroup

or Out-

group

Con-

text.

Interna-

tional

Journal

of Psy-

chology,

26,

83-94.

Braithwaite, John (1989). Crime, Shame and Reintegration. Cambridge: Cambridge University Press.

Bronson, Edward (1989). The Effectiveness of Voir Dire in Discovering Prejudice in High Publicity Cases. Chico, California: California State University, College of Behavioral and Social Sciences. 
Long, E. L. (1996). Ethnic Expressive Style and American Public Opinion: The O.J. Simpson Case ,in Greg Barak, ed, Representing O.J. :Murder, Criminal Justice and Mass Culture. Guilderland, NY: Harrow and Heston.

Darley, John and Zanna, Mark (1982). Making Moral Judgments. American Scientist, 70. $515-521$.

Durkheim, Emile (1967). The Division of Labor in Society, George Simpson, trans., Glencoe, Ill: The Free Press.

Ellsworth, Phoebe and Gross, Samuel (1994). Hardening of the Attitudes : Americans' Views on the Death Penalty. Journal of Social Issues, 50, 19-52.

Erikson, Kai (1966). Wayward Puritans: A Study in the Sociology of Deviance. New York: John Wiley \& Sons.

Felson, Richard, and Tedeschi, James (1995). A Social Interactionist Approach to Violence: Crosscultural Applications. In Barry Ruback and Neil Weiner, eds., Interpersonal Violent Behaviors: Social and Cultural Aspects. New York: Springer Publishing.

Seymour (1984). The Catharsis Hypothesis, Aggressive Drive and the Reduction of Aggression. Aggressive Behavior, 10, $91-101$.

Fletcher, George (1995). With Justice for Some: Victim's Rights in Criminal Trials. Reading Mass.: Addison-Wesley. 
Garfinkel, Harold (1956)

Conditions of Successful Degradation Ceremonies, American Journal of Sociology, 61, 420-

Gibson, James and Gouws, Amanda (1999). Truth and Reconciliation in South Africa: Attributions of Blame and the Struggle over Apartheid American. Political Science Review, 93, $501-517$.

Girard, Rene (1986). The Scapegoat. London: The Athlone Press

Graham, Sandra, Weiner, Bernard, and Zucker, Gail (1997). An Attributional Analysis of Punishment Goals and Public Reactions to O.J. Simpson, Personality and Social Psychology Bulletin, 23, 331-346.

Griffiths, Curt and Hamilton, Roy (1996). Sanctioning and Healing: Restorative Justice In Canadian Aboriginal Communities. In Burt Galaway and Joe Hudson, eds., Restorative Justice: International Perspectives pp175-191. Monsey, New York: Criminal Justice Press. .

Hamilton V. Lee and Sanders, Joseph (1992). Everyday Justice: responsibility and the individual in Japan and the United States New Haven: Yale University Press.

Heider, Fritz (1958). The Psychology of Interpersonal Relations. New York : John Wiley \& Sons Johnston, Wayne (1990/1999). The Divine Ryans. New York: Broadway Books.

Kelsen, Hans (1943). Society and Nature. Chicago: University of Chicago Press 
Kleinke, Chris, Wallis, Robert and and Stalder, Kevin (1992). Evaluations of a Rapist as a Function of Expressed Intent and Remorse. Journal of Social Psychology, 132, 525-537.

Lerner, Melvin (1977). The Justice Motive: Some Hypotheses as to Its origins and Forms, Journal of Personality, 45, 1-52.

Lerner, Melvin (1981. The Justice Motive in Human Relations: Some Thoughts on What We know and What We need to Know about Justice. In Melvin Lerner and Sally Lerner, eds, The Justice Motive in Social Behavior, pp 11-38. New York: Plenum Press

Lerner, Melvin (1987). Integrating Societal and Psychological Rules of Entitlement: The Basic Task of Each Social Actor and Fundamental Problem for the Social Sciences. Social Justice Research,1, $107-125$.

Linedecker, C. (1995).

O.J. A to Z: The Complete Handbook to the Trial of the Century. New York: St.Martins Griffin.

McGraw , Kathleen (1991). Managing Blame: An Experimental Test of the Effects of Political Accounts. American Political Science Review, 85, 1133-1157.

Marques, Jose (1990). The Black-sheep Effect: Out-group Homogeneity in Social Comparison Settings. In Dominic Abrams and Michael Hogg, eds, Social Identity Theory : Constructive and Critical Advances. New York Springer-Verlag.

Mead, George (1918). The Psychology of Punitive Justice. American Journal of Sociology,23, 577-

Meindel, James and Lerner, Melvin (1983). The Heroic Motive: Some Experimental Demonstrations, Journal of Experimental Social Psychology , 19, 1-20.

Mosteller, Robert (1997). Victims' Rights and the United States Constitution: An Effort to Recast the Battle in Criminal Litigation, Georgetown Law Review, 85, 1691-1715.

Ogloff, James and Vidmar, Neil (1994). The Impact of Pretrial Publicity on Jurors. Law and Human Behavior, 18, 507-525.

Pipes, Daniel (1990). The Rushdie Affair. New York: Birch Lane Press Books 
Daniel

(1998).

Salman

Rushdie's

Delu-

sions

and

Ours.

Com-

mentary

106

51-53.

and Darley, John (1995). Justice, Liability and Blame: Community Views of the Criminal Law. Boulder, Colorado: Westview Press.

Robinson, Dawn, Smith-Lovin, Lynn, and Tsoudis, Olga (1994). Heinous Crime or Unfortunate Accident? The Effects of Remorse on Responses to Mock Criminal Confessions. 73 Social Forces 175-190.

Rochman, Bonnie (1999). Sentenced to Public Shaming. Raleigh, North Carolina News and Observer, November 29,1999 at p A1.

Rosen, Robert (199?). Shaming Penalties and Social Forgiveness Deficit. In F. Van Loon and K. Van Aeken, eds., pp 185-191, Sociology of Law, Social Problems and Legal Policy. Amsterdam: Acco Leuven 
Rovella, David (January 12,1998). Making Sure Terry Nichols is Executed; A Mixed Verdict by Federal Jurors Turns Attention to Planned State Prosecutions. The National Law Journal, 20, A6.

Rovella, David (May 24, 1999). Nichols Faces Death a Second Time. The National Law Journal, 21, A1.

Rovella, David (July 31, 2000). It's Oklahoma's Turn. The National Law Journal, 22, A1.

Sarat, Austin (1997). Vengeance, Victims, and the Identities of Law. Social and Legal Studies, 6, 163-189.

$$
\text { Scheff, Thomas and }
$$

Bushell, Don (1984). A Theory of Catharsis. Journal of Research in Personality, 18, 238-264.

Schultz, Thomas and Darley, John (1991). An information-processing model of retributive moral Judgments based on "legal reasoning." In William.Kurtines and Jacob Gewirtz, Handbook of Moral Behavior and Development, Vol 2 (pp247-278) Hillsdale, NJ : Lawrence Erlbaum. 
Stuart,

Barry (1996). Circle Sentencing: Turning Swords into Plowshares. In Burt Galaway and Joe Hudson, eds., Restorative Justice: International Perspectives pp193-206. Monsey, New York: Criminal Justice Press.

Studebaker, Chritina, Robbennolt, Jennifer, PathakSharma, Maithilee, and Penrod, Steve (2000). Assessing Pretrial Publicity Effects: Integrating Content Analytic Results. Law and Human Behavior ,24, 317-336.

Sundby, Scott (1998). The Capital Jury and Absolution: The Intersection of Trial Strategy, Remorse, and the Death Penalty. Cornell Law Review ,83, 1557-1598).

Thaman, Steven (2000). Europe's New Jury Systems: The Cases of Spain and Russia. In Neil Vidmar, ed., World Jury Systems. Oxford, England: Oxford University Press.

Thomas, W.I., and Znaniecki, Florian (1943). The Polish Peasant in Europe and America , Vol 2, Chicago: University of Chicago Press.

Tyler, Tom and Boeckman, Robert (1997). Three Strikes and You are Out, but Why? The Psychology of Public Support for Punishing Rule Breakers. Law \& Society Review,31, 237-265.

U.S. v. McVeigh, 918 Federal Supplement,1467 (1996).

U.S. v. McVeigh, 955 Federal Supplement, 1281 (1997).

Vidmar, Neil (1991). Prejudicial Pre-trial Prejudice in R.v. Kenny. Report and oral testimony

Affidavit submitted to Supreme Court of Newfoundland, St.John's Newfoundland, Canada 
Vidmar, Neil (2001). Retribution and Revenge. In Joseph Sanders and V. Lee Hamilton, eds, Handbook of Justice Research in Law. New York: Kluwer Academic/ Plenum Publishers.

Vidmar, Neil (2000). An Assessment of Public Opinion in Frontenac County Ontario Regarding R.v. Louise Reynolds. Superior Court of Ontario April 17, 2000.

Vidmar, Neil and Melnitzer, Julius (1984). Juror Prejudice: An Empirical Study of a Challenge for Cause. Osgoode Hall Law School,22, 487-511.

Vidmar, Neil and Miller, Dale. (1980) Socialpsychological Processes Underlying Attitudes Toward Legal Punishment, Law \& Society Review, 14, 565- 602.

Will, George (1996) Restore the Sting of Shame Raleigh North Carolina, News and Observer, February $1,1996 \mathrm{p} 13 \mathrm{~A}$. 